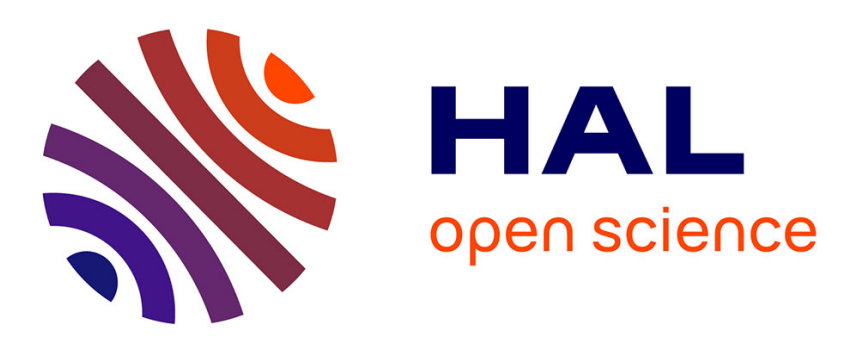

\title{
Hydraulic preferences of shrimps and fishes in tropical insular rivers
}

Virginie Grandgirard, Dominique Monti, P. Valade, Nicolas Lamouroux, J.P. Mallet, H. Grondin

\section{- To cite this version:}

Virginie Grandgirard, Dominique Monti, P. Valade, Nicolas Lamouroux, J.P. Mallet, et al.. Hydraulic preferences of shrimps and fishes in tropical insular rivers. River Research and Applications, 2014, 30 (6), p. 766 - p. 779 . 10.1002/rra.2675 . hal-01072479

\section{HAL Id: hal-01072479 \\ https://hal.science/hal-01072479}

Submitted on 8 Oct 2014

HAL is a multi-disciplinary open access archive for the deposit and dissemination of scientific research documents, whether they are published or not. The documents may come from teaching and research institutions in France or abroad, or from public or private research centers.
L'archive ouverte pluridisciplinaire HAL, est destinée au dépôt et à la diffusion de documents scientifiques de niveau recherche, publiés ou non, émanant des établissements d'enseignement et de recherche français ou étrangers, des laboratoires publics ou privés. 
1 Hydraulic preferences of shrimps and fishes in tropical insular rivers

2

3 Virginie Girard ${ }^{1,2}$, Dominique Monti $^{3}$, Pierre Valade ${ }^{4}$, Nicolas Lamouroux ${ }^{1}$, Jean-Paul

4 Mallet $^{2}$, Henri Grondin ${ }^{5}$.

6 Short title: Hydraulic preferences of diadromous species

8 Key words: micro-habitat preferences; generalized additive models; transferability;

9 Caribbean; Indian Ocean

${ }^{1}$ IRSTEA Lyon, UR MALY, 5 rue de la Doua CS70077 69626 VILLEURBANNE Cedex, France, virginie.girard@irstea.fr, nicolas.lamouroux@irstea.fr

$14{ }^{2}$ ASCONIT Consultants, Espace Scientifique Tony Garnier, 6-8 Espace Henry Vallée, 69366 LYON Cedex 07, 15 jp.mallet@asconit.com

$16{ }^{3}$ EA926 DYNECAR, Université des Antilles et de la Guyane, Fouillole, BP 250, 97157 Pointe-à-Pitre,

17 dominique.monti@univ-ag.fr

$18{ }^{4}$ O.C.E.A. Consult', Organisme Consultant en Environnement Aquatique, BP 22, Centre Régional d'Application 19 Aquacole 97427 Etang Salé, pierre.valade@ocea.re

$20 \quad{ }^{5}$ A.R.D.A., B.P. 16, Z.I. Les Sables, 97427 Etang Salé, grondin.arda@ wanadoo.fr

22 Correspondence to: V. Girard, IRSTEA Lyon, UR MALY, 5 rue de la Doua CS70077 69626 Villeurbanne 


\section{ABSTRACT}

Hydraulic habitat models based on the preferences of species for the hydraulic characteristics of their microhabitats are frequently used to evaluate the impact on the habitat of a change in river flow regime. Their application in a tropical insular environment is still limited as little is known about the hydraulic preferences of species. Hydraulic preferences models have been developed for 15 taxa (diadromous shrimps and fishes) sampled in 52 rivers in the Caribbean (the French West Indies) and the Indian Ocean (the Reunion island). Five datasets were used and group 8353 samples collected by electrofishing during 320 surveys (reach×date)

performed between 1999 and 2011. Generalised additive models were used to link variations of taxa density within surveys to the hydraulic characteristics of the microhabitat (velocity, depth, substrate). Hydraulic preferences within each region (Caribbean and Indian Ocean) are significant for most of the taxa and vary little between rivers and surveys. The hydraulic variables explain up to $18.1 \%$ (univariate models) and $30.0 \%$ (multivariate models) of the deviance of densities within survey. Of the taxa selected, Atya scabra, Macrobrachium heterochirus, Xiphocaris elongata and the Sicydiinae are the most demanding. 


\section{INTRODUCTION}

Tropical insular rivers are characterised by extreme and unpredictable hydrological events (typhoons, cyclones, Tew et al., 2002) that alternate with sometimes severe periods of low flow (Covich, 2006) that are decisive for aquatic communities (Poff and Ward, 1989). The communities of these rivers are characterised by low density and are mainly composed of three families of shrimp (Atyidae, Palaemonidae, Xiphocaridae) and four families of fish (Eleotridae, Gobiidae, Mugilidae and Anguillidae) (Covich and McDowell, 1996), all of which are diadromous (McDowall, 2004). The catadromous species (Mugilidae, Anguillidae) spend their lives in rivers and reach the sea and/or river outlets to reproduce. Amphidromous species (Atyidae, Palaemonidae, Xiphocaridae, Gobiidae) spawn and grow in freshwater except during larval stages which require a saline environment. The complex lifecycle of these species makes them especially vulnerable to increasing demographic pressure (Mittermeier et al., 2005; Smith et al., 2008), such as dams that modify flow regimes and river habitats, and impede their migrations (March et al., 2003; Milton, 2009). Many aspects of the flow regime may affect the habitats and the life cycle of tropical species (e.g. Welcomme and Halls, 2004). For example, the timing and the amplitude of floods may trigger fauna migration and reproduction (e.g. Way et al., 1998; Blanco and Scatena, 2005; Kikkert et al., 2009). However, little is known about the ecological impact of changes in low to moderate flows (Pringle et al., 2000; Monti and Legendre, 2009).

Hydraulic habitat models have been used widely around the world to facilitate the management of low to medium discharges (Tharme 2003; Conallin et al., 2010). This method uses models that predict the amount of favourable habitat at the reach scale $\left(\sim 10^{2}-10^{3} \mathrm{~m}^{2}\right)$ as a function of discharge rate (Bovee, 1982; Ginot, 1995). Habitat models combine the hydraulic model of a stream reach with models of hydraulic preferences. Classically, hydraulic 
preference models represent how the abundance or occurrence of a taxon (e.g. guild of species, species, life stage of a species) varies within the reach as a function of microhabitat parameters (e.g. velocity, depth, substrate). The applicability of habitat models is generally limited by their degree of transferability between rivers (Jowett, 2003; Lamouroux et al., 2010; Lancaster and Downes, 2010). Indeed, habitat preferences can vary as a function of a large number of biotic and abiotic factors such as competition, predation, and water chemistry (Jackson et al., 2001). In order to better quantify the generality of hydraulic preference models, it is therefore interesting to study the hydraulic preferences of taxa using data collected from different rivers at different times (seasons, years) (Leftwich et al., 1997; Lamouroux et al., 1999a; Strakosh et al., 2003; Vilizzi et al., 2004; Dolédec et al., 2007; Mérigoux et al., 2009). The models developed at several sites have led to contrasting conclusions, but have often highlighted the pertinence of models defined for a number of rivers sharing the same hydromorphological characteristics (Lamouroux et al., 1999b; Lamouroux et al. in press).

Not much is known about the hydraulic preferences of tropical river species (Pringle $e t$ al., 2000; Scatena, 2004; Boulton et al., 2008). Research into these species has mainly focused on (1) the altitudinal distribution of species and the importance of maintaining upstream/downstream connectivity (Holmquist et al., 1998), (2) trophic links and the role of macro-consumers (Crowl et al., 2006; Coat et al., 2009), (3) the effects of extreme events on population structures (e.g. the harmful effect of low water levels on the abundance of Macrobrachium sp., Covich et al., 2006) and (4) the mechanisms and role of dispersion in population renewal (Keith et al. 2008; Crook et al., 2009). However, few works have focused on the role of hydraulic constraints (e.g. shift of driving force under natural disturbance, Monti and Legendre, 2009) and the habitat selection mechanisms at the reach scale (e.g. habitat selection for Sicydiinae, Teichert et al. in press). 
In this study, we examine how the density of 15 taxa of the families of Atyidae,

Palaemonidae, Xiphocaridae, Gobiidae and Mugilidae vary as a function of the hydraulic parameters of the microhabitat (velocity, depth, substrate). The datasets used come from two regions: the French West Indies (Martinique, Guadeloupe) in the Caribbean and the island of Reunion in the Indian Ocean. These are recent volcanic islands with comparable hydromorphological characteristics (narrow valleys, abrupt reliefs, high waterfalls) (Falkland, 1992). Our main objectives were to (1) build hydraulic preference models for different taxonomic groups in each of the two regions (Caribbean, Indian Ocean), (2) estimate the transferability of models among datasets and groups of surveys, and (3) compare hydraulic preferences among the species of the same family.

\section{Reaches and sampling dates}

We used five datasets (Table 1), three collected from the Caribbean and two from the Indian Ocean (Figure 1). Abundance samples were taken in 121 reaches of 52 rivers during periods of 1 to 12 years. The reaches were distributed over the entire island, in river sections with persistent flows, and were sometimes located upstream or downstream of water intakes. The length of the reaches varied from 0.05 to $2.75 \mathrm{~km}$ so that each reach encompassed a variety of morphological units (e.g. riffles, rapids, pools, cascades). The reaches were located at an altitude between 5 and $670 \mathrm{~m}$, at a distance from the sea from 0.1 to $22.8 \mathrm{~km}$ and at a distance of 1 to $34.5 \mathrm{~km}$ from the source. The surface area of the watersheds upstream of the reach was on average ( \pm standard deviation) $15\left( \pm 15 \mathrm{~km}^{2}\right)$ in the Caribbean and $70\left( \pm 49 \mathrm{~km}^{2}\right)$ in the Indian Ocean. Most of the sampling was performed during the low flow period (when hydraulic selection occurs), i.e. from December to May in the Caribbean (Chaperon et al., 1983) and from November to April in the Indian Ocean (Robert, 1988). 20\% of the surveys 
118 (reach $\times$ date) in the Caribbean were carried out during the high flow period but when

119 discharge rate was relatively low.

\section{Sampling methods}

122 Sampling of fishes and shrimps was done by electrofishing using three methods (Table 1)

123 according to the objectives of previous studies (e.g. analysis of spatial patterns, Monti and

124 Legendre, 2009). The "points" method consisted in collecting 50 samples $\left(\sim 1 \mathrm{~m}^{2}\right)$ distributed

125 randomly in the reach by positioning a portable electrode (e.g. DEKA 3000 Lord; DEKA-

126 Gerätebau, Marsberg, Germany) without moving it (Fiévet et al., 1996). The "habitat units"

127 method consisted in fishing about 20 samples from wider surface areas distributed in the

128 available morphological units. The surface area of the samples was $17 \mathrm{~m}^{2}$ on average $( \pm 8$

$129 \mathrm{~m}^{2}$ ). The "quadrats" method consisted in fishing about 90 contiguous samples (squares of

130 surface area $=4 \mathrm{~m}^{2}$ ) in the reaches. These different methods have been used by different

131 teams and were not intercalibrated in our reaches. However, point samples and habitat unit

132 samples have already been combined in habitat modelling. For example, Lamouroux et al.

133 (1999b) predicted fish density differences between reaches sampled by points from preference

134 models made in other reaches sampled by habitat units.

Each sample was characterised by three microhabitat variables: average velocity $(v)$,

137 average water depth $(h)$ and the size of the substrate $(d), v, h$ and $d$ were estimated on the

138 basis of measurements along one vertical (44\% of cases) or several verticals distributed in the

139 sampling area (56\% of cases). On each vertical, point velocities were measured using a

140 current meter (a propeller for dataset Gq; an electromagnetic current meter for the other

141 datasets) at $0.2 h, 0.4 h$ and $0.8 h$ at the bottom of the bed when $h>0.20 \mathrm{~m}$, otherwise at $0.4 h$.

142 However, $5.4 \%$ of the velocities were estimated at the water surface as a function of the

143 distance travelled by a float over a given time. The dominant substrate size $d$ of the sample 
144 area was estimated visually using ordinal classes (Cailleux 1954; Malavoi and Souchon,

145 1989). The central value of the class of substrate was assigned to $d$.

146 Each individual fish was measured and identified at species level (Keith et al., 1999,

147 Lim et al., 2002, Monti et al., 2010), except for three taxa in the Caribbean (Table 1):

148 Sicydium sp. groups two species of fish, Sicydium punctatum and Sicydium plumeri, of the

149 Gobiidae family (subfamily Sicydiinae); Atya sp. groups the juvenile shrimps of Atya scabra

150 et Atya innocous; and Macrobrachium sp. groups the juvenile shrimps of the family of

151 Palaemonidae (subfamily Macrobrachium). However, the individuals of dataset Gq (Table 1)

152 were not measured.

154 Taxa selected

155 Of the 21 to 28 species sampled in each dataset (Table 1) only the taxa with a total abundance

$156>200$ individuals were chosen for the analysis. Therefore, we selected 11 taxa in the

157 Caribbean belonging to three families of shrimp (Atyidae, Xiphocariidae, Palaemonidae) and

158 two families of fish (Mugilidae, Gobiidae), and four taxa in the Indian Ocean belonging to

159 two families of shrimp (Atyidae, Palaemonidae) and one family of fish (Gobiidae) (Table 2).

160 In order to get round the problem of different surface areas of the samples used in the

161 analyses, the abundances of the samples were transformed to densities ( $\check{\mathrm{D}}$, number of each for

162 an equivalent surface of $10 \mathrm{~m}^{2}$ ). Taxa size classes were defined in order to infer the effect of

163 size preferences on hydraulic. The limits of classes were chosen to obtain comparable

164 numbers. 


\section{Statistical modelling}

167 For each taxon of each region, we modelled the $\check{\mathrm{D}}$ as a function of microhabitat variables with 168 a series of generalised additive models (GAMs). GAMs permit considering nonlinear

169 relations, that are frequent when studying hydraulic preferences (e.g., Lamouroux et al.,

170 1999a; Jowett et al., 2008). They have a flexible structure that does not require prior

171 determination of the form of the relation (Guisan and Zimmerman, 2000, Guisan et al., 2002).

172 Six models (Eqs. 1-6) were defined with a log link function. The reference model M1 (Eq. 1)

173 assumes that the density is constant by survey, so that there is no hydraulic preference. Model

174 M2 (Eq. 2) defines the regional model where the abundance varies similarly in each survey as

175 a function of a microhabitat variable. By comparing M2 in relation to M1, we quantify the

176 strength of hydraulic preference independently of the other biotic and abiotic factors acting at

177 the scale of the reach on a given date. In model M3 (Eq. 3), the hydraulic preferences can vary

178 as a function of the dataset, i.e. the island or the sampling method. In model M4 (Eq. 4), the

179 hydraulic preferences can vary as a function of the dataset and groups of surveys. The latter

180 two models permit appreciating the transferability of the results between rivers. Different

181 criteria were used to define two groups of surveys in M4 (with comparable numbers): the

182 season of low and high flow in the Caribbean; the years $<$ and $\geq 2009$ in the Caribbean and

183 the years $<$ and $\geq 2005$ in the Indian Ocean; the altitude $(\leq$ or $>165 \mathrm{~m}$ in the Caribbean; $<$

184 and $\geq 80 \mathrm{~m}$ in the Indian Ocean); the wind coast exposure (exposed or not); the size of the

185 watershed ( $\leq$ or $>10 \mathrm{~km}^{2}$ in the Caribbean; $\leq$ or $>50 \mathrm{~km}^{2}$ in the Indian Ocean); the situation

186 in relation to water intakes (upstream of an intake or not; only in the Caribbean). Lastly,

187 models M5 and M6 (Eqs. 5-6) define multivariate models for a taxon with or without a term

188 of interaction between microhabitat variables. Concerning the preference models of taxa size

189 classes, we fitted M1 and M2 only. Our series of models is: 
$191 \quad \mathrm{M} 2: \quad \log (\check{\mathrm{D}}) \sim a_{\text {survey }}+\mathrm{s}(\mathrm{p})$

192 M3: $\quad \log (\check{\mathrm{D}}) \sim a_{\text {survey }}+\mathrm{s}(\mathrm{p})+\mathrm{s}\left(\mathrm{p}: \mathrm{p}_{\text {dataset }}\right)$

M4: $\quad \log (\check{\mathrm{D}}) \sim a_{\text {survey }}+\mathrm{s}(\mathrm{p})+\mathrm{s}\left(\mathrm{p}: \mathrm{p}_{\text {dataset }}\right)+\mathrm{s}\left(\mathrm{p}: \mathrm{p}_{\text {survey }}\right)$

$194 \quad$ M5: $\quad \log (\check{\mathrm{D}}) \sim a_{\text {survey }}+\mathrm{s}(v)+\mathrm{s}(h)+\mathrm{s}(d)$

M6: $\quad \log (\check{\mathrm{D}}) \sim a_{\text {survey }}+\mathrm{s}(v)+\mathrm{s}(h)+\mathrm{s}(d)+\mathrm{s}(v, h, d)$

196 where p corresponds either to $v, h$ or $d$; s() is a smoothing function (of cubic spline type); p:

$197 \mathrm{p}_{\text {dataset }}$ is the term of interaction between the hydraulic variable and the dataset variable;

$198 \mathrm{p}: \mathrm{p}_{\text {survey }}$ is the term of interaction between the hydraulic variable and a group of surveys. The

199 parameter $a_{\text {survey }}$ permits ignoring differences in density between surveys which do not reflect 200 the microhabitat hydraulic preferences.

For all the models, we chose a negative binomial (NB) type error distribution, which 202 can account for the over-dispersion of abundance data, as suggested by Gray et al. (2005, freshwater macro-invertebrates) and Vaudor et al. (2009, freshwater fishes) for data of the same type. We set the dispersion parameter $(\theta)$ of the NB distribution for each taxon when fitting model M1. We also set the degree of freedom of the smoothing function of the GAMs at three to avoid any over-parameterisation (Jowett et al., 2008). Lastly, for each taxon we 207 eliminated the surveys where the number of individuals was less than three. The models were 208 fitted using the functions available in the $m g c v$ package (Wood, 2006) of the R software (R 209 Development Core Team, 2010).

211 M6) using the additional deviance explained in comparison to the previous model. In 212 addition, we used a likelihood ratio test to compare a given model with the previous one. 
215 A total of 8353 samples were collected from 320 surveys, making it possible to establish and study the preferences of 11 taxa and 16 size classes in the Caribbean, four taxa and eight size classes in the Indian Ocean (Table 2). The velocities of the samples varied from 0 to $2.80 \mathrm{~m} . \mathrm{s}^{-}$

$218{ }^{1}$, the depths from 0.02 to $1.90 \mathrm{~m}$ and the substrate from 0 to $1.024 \mathrm{~m}$.

The dispersion parameter $\theta$ varied from 0.06 (A. scabra) to $0.46(M$. poeyi) for the taxa of the Caribbean, and from 0.32 (A. serrata) and 1.10 (S. lagocephalus) for the taxa of the Indian Ocean (Table 2, standard error on $\theta \leq 0.03$ for all species). The low values of $\theta$, which indicate over-dispersion of densities, were obtained for rare species (M. crenulatum, $A$. monticola ) and those known to be gregarious (A. scabra; Lim et al., 2002; Monti et al., 224 2010).

Univariate models $M 1-M 4$ by taxon

The deviance explained by the survey in reference model M1 varied from 20.3 to $56.0 \%$ (on average $36 \%$, Table 3). The addition of microhabitat variables in M2 explained from 0 to $18.1 \%$ (average $4.3 \%$ ) of the residual deviance of M1. The model of velocity preferences was generally more efficient than that of preferences of depths and substrates (on average 6.9, 4.4 and $1.6 \%$ of explained deviance, respectively). Examples of fits of M2 models to the data observed are given in Figure 2.

Hydraulic preferences were significant for most of the species, except A. monticola ( $v$ and $d)$, M. crenulatum, Atya sp. and X. elongata (d) (Table 3). The strongest preferences, relative to velocity and depth, concerned A. Scabra, M. heterochirus, X. elongata and Sicydium sp. in the Caribbean and S. lagocephalus and C. acutipinnis in the Indian Ocean. 
intermediate (A. innocous, M. poeyi) or high (A. Scabra, M. heterochirus, A. serrata and

239 Sicydiinae) velocities, whereas most taxa preferred shallow depths, except X. elongata, M.

240 crenulatum and M. australe (Figures 3 and 4). A. scabra, M. heterochirus, A. serrata, $C$.

241 acutipinnis and S. lagocephalus preferred coarse substrates whereas $M$. australe preferred fine 242 substrates (Figures 3 and 4).

The preferences for velocities and depths, and to a lesser extent substrates (Table 3),

244 differed between datasets. However, the additional deviance explained by M3 in comparison 245 to M2 remained low: it was $<2.2 \%$ in the Caribbean and $<1.5 \%$ in the Indian Ocean (Table 246 3). The main differences observed in the Caribbean are the variations of preferences in the 247 range of high velocities $\left(>0.5 \mathrm{~m} . \mathrm{s}^{-1}\right)$ (cf. A. scabra in Figure 3) and preferences for shallower 248 or deeper water depths (cf. A. monticola in Figure 3). In the Indian Ocean, we observed 249 preferences for lower velocities and an absence of preferences for depths in the dataset 250 sampled by "points" in comparison to "habitat units" for C. acutipinnis $(v, h)$ (Figure 4). 251 Regarding variations between groups of surveys, the comparison of M4 and M3 indicated that 252 the localisation parameters of reaches and the sampling period generally had little influence 253 on hydraulic preferences (explained relative deviance $<2.4 \%$, Table 3 ). The highest values

254 observed concerned A. scabra in the Caribbean, and A. serrata, M. australe and C. acutipinnis 255 in the Indian Ocean.

258 The hydraulic preferences according to size classes were mostly significant except for the 259 preferences of $X$. elongata $(h)$, A. monticola $(h)$ and $A$. serrata $(d)$ of small sizes and the 260 preferences of adults of Sicydium sp. $(d)$ and A. monticola (v) (Table 4, Figure 5). The 261 deviance explained by the models by size classes was close to that of the model by taxon. The 262 deviance explained was nonetheless higher for size classes concerning the preferences for 
263

264

substrate. The preferences of larger individuals for velocities were weaker than those of smaller individuals for the species A. scabra and X. elongata; on the contrary, the preferences of larger individuals for velocities were stronger than those of smaller individuals for the species Sicydium sp.. Size classes generally preferred similar depth ranges except for the taxa X. elongata, where larger individuals tended to prefer deeper habitats (Figure 5). The preferences of larger individuals for substrate are weaker than those of smaller individuals for M. australe and M. heterochirus; conversely, larger individuals of A. scabra, A. serrata and $S$. lagocephalus have stronger preferences for substrate.

\section{Multivariate models M5 - M6}

The multivariate models without interactions (M5) explained from 2.8 to $24.4 \%$ of the residual deviance of M1 (Table 5). The addition of an interaction term (M6) improved the explained deviance between 3.7 and $9.4 \%$ for some taxa: Sicydium sp., X. elongata, $C$. acutipinnis and S. lagocephalus (Table 5).

\section{DISCUSSION}

The within-survey deviance explained by microhabitat variables varies between 0 and $18.1 \%$ (univariate regional models) and from 4.1 to $30.0 \%$ (multivariate regional models). The poor performances achieved by the models built are partly due to the small size of the scale of observation $\left(\sim 1 \mathrm{~m}^{2}\right)$ and likely result from the particular life cycle of the taxa (diadromous and opportunistic species). Similarly, the within-survey deviance of models of hydraulic preferences of the white shrimp Paranephrops planifrons, a diadromous species of the rivers of the north island of New Zealand, varies from 7 and 11\% (Jowett et al., 2008). By way of 
comparison, Dolédec et al. (2007) showed that models of European regional preferences for macro-invertebrates explained on average $25 \%$ of within-survey variance.

Taxa showing the most marked hydraulic preferences are A. scabra, M. heterochirus, $X$.

Ocean. For example, the density of A. scabra and X. elongata can be multiplied by a factor of $\sim 5$ for a change of velocity in the order of $0.5 \mathrm{~m} \cdot \mathrm{s}^{-1}$. densities of drifting benthos, particles and/or individuals are higher (Orth and Maughan, 1983; Brooks et al., 2005). Furthermore, the feeding mode of A. scabra is probably more specialised than for A. innocous, likewise with M. heterochirus in comparison to M. crenulatum. On the contrary, X. elongata has a strong preference for low velocities and deeper water since it lives essentially in the water column (Lim et al., 2002). In addition, our results corroborate those of Monti and Legendre (2009) who showed that M. heterochirus and X. elongata have notable preferences for velocities in environments with strong hydrological disturbances. preferences are probably linked to the presence of periphytic biofilm whose quality and 308 development are conditioned by bed shear stress and light, respectively (Julius et al., 2005; 309 Lefrançois et al., 2011; Tabouret et al., 2011). The hydraulic preferences of S. lagocephalus 310 and C. acutipinnis are comparable to those given by the logistic models built by Teichert et al. 311 (in press), except that the authors showed that $C$. acutipinnis has stronger preferences for 
312 depths than velocities. This difference in preference strength can be due to the longer

313 sampling period covered by our dataset.

314 Taxa showing weaker hydraulic preferences are A. monticola, M. faustinum, $M$.

crenulatum, M. australe, A. innocous, $M$. poeyi and the juvenile shrimps of the Caribbean.

These results are consistent with those of Monti and Legendre (2009) who reported weak and Legendre identified strong preferences for low velocities for four sites under strong and weak hydrological disturbance, suggesting that food predominates in influencing habitat selection. Some of these species are also described with preference variables according to diurnal phases (e.g. A. innocous) (Keith et al., 1999; Lim et al., 2002; Monti et al., 2010). The weak preferences of the species observed here can also be partly due to variations in fishing efficiency or to our grouping of juveniles of some taxa (A. scabra and A. innocous; $M$. crenulatum, $M$. heterochirus and $M$. faustinum). Regarding fishing efficiency, it is as poor as the species are rare (M. crenulatum) and their mobility is high (A. monticola) (Fiévet et al., 1999; King et al., 2002). It is therefore possible that fishing efficiency explains the absence of preference for velocity that we observed for the mobile A. monticola, whereas the taxon is expected to prefer fast and well oxygenated water (Lim et al., 2002). Fishing efficiency can also explain that we observed weak preferences for A. innocous, which is an excellent swimmer and very reactive in the presence of predators (Covich et al., 2009; Hein and Crowl, 2010) or when disturbed by electrofishing (Fiévet et al., 1999). Regarding the shrimp $M$. australe, its weak regional preferences can be explained by its sheltering behaviour during the day and variation due to its morphological plasticity (Zimmermann et al., 2012). The grouping of juveniles of different species of Macrobrachium is probably not very appropriate since we observed that the adults of M. faustinum and M. heterochirus have different preferences (forces and directions) regarding velocity and depth. This is less the case for the 
relatively similar preferences. Lastly, the more flexible mode of feeding (filtering and scraping) of $M$. poeyi and A. innocous in comparison to A. scabra (mainly filtering) can also explain less selective use of microhabitats.

342 (filtering and/or scraping) and morphological adaptations (size, apical spine) effectively

343 influence habitat selection. This result supports that aquatic taxa have developed strategies

344 shaped by the flow regime (Poff and Ward, 1989; Poff, 1997). The use of life history traits is

345 therefore encouraged for overcoming problems of identification and/or lack of data on a 346 particular species (Blanck et al., 2007).

The low additional deviance explained by datasets or groups of surveys suggests that regional models are pertinent for expressing taxa preferences. Likewise, the performance of models regarding size class does not suggest a notable improvement. These results should nonetheless be seen relatively. For example, it is possible that our definitions of groups are not very appropriate for expressing different competition conditions. These effects can exist for certain species (S. lagocephalus and C. acutipinnis, Lord et al., 2011) and might partially explain the variations observed between groups in our results (C. acutipinnis). Likewise, taking the hydrological regime (Monti and Legendre, 2009) into account in more detail would undoubtedly lead to more thorough models. Lastly, a breakdown of taxa by life stage rather than by size class could be more pertinent to reflect the physiological needs of species (Bielsa et al., 2003, for S. lagocephalus) and their behaviours regarding different predators (e.g. longer rostrum in X. elongata in the presence of predatory fish, Covich et al., 2009).

361 To sum up, the hydraulic preferences of insular tropical taxa are generally weaker than in temperate regions. This observation, as well as the complexity of the life cycle of these taxa, 
364 within an approach that provides a more general description of their habitat during their life

365 cycle. This approach would imply in particular taking into account the ecological effect of

366 various flow regime attributes (e.g., timing and duration of floods, flashiness; Bunn and

367 Arthington, 2002), the longitudinal connectivity (e.g., Greathouse et al., 2006) and the

368 potential threat of introduced species (Donlan and Wilcox, 2008). Nonetheless, our results

369 show that the hydraulic preferences of certain taxa are significant (e.g., A. scabra, $M$.

370 heterochirus) and consistent with the knowledge available on these taxa. Our regional models

371 can contribute to describe the hydraulic preferences of these taxa and model how the management of low to average discharges modifies their available habitat.

\section{ACKNOWLEDGMENTS}

375 We thank the staff from "Association Réunionnaise de Développement de l'Aquaculture" and 376 from Asconit Consultants for their collaboration in this project and for collecting part of the

377 data. We also thank Sylvie Mérigoux, Jean-Michel Olivier, Philippe Keith and Thierry

378 Oberdorff for helpful discussions. The "Direction Régionale de l'Environnement, de

379 l'Aménagement et du Logement" of Guadeloupe, the "Office de l'eau" of Martinique and

380 "Office de l'eau" of Reunion provided financial support. 


\section{REFERENCES}

Bielsa S, Francisco P, Mastrorillo S, Parent JP. 2003. Seasonal changes of periphytic nutritive quality for Sicyopterus lagocephalus (Pallas, 1770) (gobiidae) in three streams of Reunion Island. Annales De Limnologie-International Journal of Limnology 39:115-127.

Blanck A, Tedesco PA, Lamouroux N. 2007. Relationships between life-history strategies of European freshwater fish species and their habitat preferences. Freshwater Biology 52:843-859.

Boulton AJ, Boyero L, Covich AP, Dobson M, Lake S, Pearson R. 2008. Are tropical streams ecologically different from temperate streams? In Tropical Stream Ecology, Dudgeon D (ed.). Academic Press (Aquatic Ecology Series): London; 257-284.

Bovee KD, 1982. A guide to stream habitat analysis using the instream flow incremental methodology. instream flow information. In Western energy and land use team, U.S. Fish and wildlife Service (ed.): Fort Collins, Colorado.

Brooks AJ, Haeusler T, Reinfelds I, Williams S. 2005. Hydraulic microhabitats and the distribution of macroinvertebrate assemblages in riffles. Freshwater Biology 50:331-344.

Bunn SE. \& Arthington AA. 2002. Basic principles and ecological consequences of altered flow regimes for aquatic biodiversity. Environmental Management, 30: 492-507.

Cailleux A. 1954. Limites dimensionnelles des noms des fractions granulométriques. Bulletin de la Société géologique de France 4: 643-646.

Chaperon P, L'Hôte Y, Vuillaume G. 1983. Les ressources en eaux de surface de la Guadeloupe. Cahier ORSTOM, Série Hydrologie 20:149-178.

Coat S, Monti D, Bouchon C, Lepoint G. 2009. Trophic relationships in a tropical stream food web assessed by stable isotope analysis. Freshwater Biology 54:1028-1041.

Conallin J, Boegh E, Jensen JK. 2010. Instream physical habitat modelling types: An analysis as stream hydromorphological modelling tools for EU water resource managers. 
International Journal of River Basin Management 8:93-107.

Covich AP. 2006. Dispersal - Limited biodiversity of tropical insular streams. Polish Journal of Ecology 54:523-547.

Covich AP, Mcdowell WH. 1996. The stream community. The Food Web of a Tropical Rain Forest 433-459.

Covich AP, Crowl TA, Heartsill-Scalley T. 2006. Effects of drought and hurricane disturbances on headwater distributions of palaemonid river shrimp (Macrobrachium spp.) in the Luquillo Mountains, Puerto Rico, Journal of the North American Benthological Society 25:99-107.

Covich AP, Crowl TA, Hein CL, Townsend MJ, Mcdowell WH. 2009. Predator-prey interactions in river networks: comparing shrimp spatial refugia in two drainage basins. Freshwater Biology 54:450-465.

Crook KE, Pringle CM, Freeman MC. 2009. A method to assess longitudinal riverine connectivity in tropical streams dominated by migratory biota. Aquatic Conservation: Marine and Freshwater Ecosystems 19:714-723.

Crowl TA, Welsh V, Heartsill-Scalley T, Covich AP. 2006. Effects of different types of conditioning on rates of leaf-litter shredding by Xiphocaris elongata, a Neotropical freshwater shrimp. Journal of the North American Benthological Society 25:198-208.

Dolédec S, Lamouroux N, Fuchs U, Mérigoux S. 2007. Modelling the hydraulic preferences of benthic macroinvertebrates in small European streams. Freshwater Biology 52:145164.

Falkland AC. 1992. Small tropical islands: water resources of paradise lost. IHP Humid Tropics Programme Series 2. UNESCO: Paris.

Fiévet E, De Morais LT, De Morais AT. 1996. Quantitative sampling of freshwater shrimps: Comparison of two electrofishing procedures in a Caribbean stream. Archiv fur 
Hydrobiologie 138:273-287.

Fiévet E, Bonnet-Arnaud P, Mallet JP. 1999. Efficiency and sampling bias of electrofishing for freshwater shrimp and fish in two Caribbean streams, Guadeloupe Island. Fisheries Research 44:149-166.

Ginot V. 1995. EVHA, a Windows software for fish habitat assessment in streams. Bulletin Francais de la Peche et de la Pisciculture 303-308.

Gray BR. 2005. Selecting a distributional assumption for modelling relative densities of benthic macroinvertebrates. Ecological Modelling 185:1-12.

Guisan A, Zimmermann NE. 2000. Predictive habitat distribution models in ecology. Ecological Modelling 135:147-186.

Guisan A, Edwards jr TC, Hastie T. 2002. Generalized linear and generalized additive models in studies of species distributions: Setting the scene. Ecological Modelling 157:89-100.

Hein CL, Crowl TA. 2010. Running the predator gauntlet: do freshwater shrimp (Atya

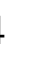
lanipes) migrate above waterfalls to avoid fish predation? Journal of the North American Benthological Society 29:431-443.

Holmquist JG, Schmidt-Gengenbach JM, Yoshioka BB. 1998. High dams and marinefreshwater linkages: Effects on native and introduced fauna in the Caribbean. Conservation Biology 12:621-630.

Jackson DA, Peres-Neto PR, Olden JD. 2001. What controls who is where in freshwater fish communities - the roles of biotic, abiotic, and spatial factors. Canadian Journal of Fisheries and Aquatic Sciences 58:157-170.

Jowett IG. 2003. Hydraulic constraints on habitat suitability for benthic invertebrates in gravel-bed rivers. River Research and Applications 19:495-507.

Jowett IG, Parkyn SM, Richardson J. 2008. Habitat characteristics of crayfish (Paranephrops planifrons) in New Zealand streams using generalised additive models (GAMs). 


\section{Hydrobiologia 596:353-365.}

Julius M, Blob R, Schoenfuss H. 2005. The survival of Sicyopterus stimpsoni, an endemic amphidromous Hawaiian gobiid fish, relies on the hydrological cycles of streams: evidence from changes in algal composition of diet through growth stages fish. Aquatic Ecology 39:473-484.

Keith P, Vigneux E, Bosc P. 1999. Atlas des poissons et crustacés d'eau douce de la Réunion. Muséum national d'Histoire naturelle 39: Paris.

Keith P, Hoareau TB, Lord C, Ah-yane O, Gimonneau G, Robinet T, Valade P. 2008. Characterisation of post-larval to juvenile stages, metamorphosis and recruitment of an amphidromous goby, Sicyopterus lagocephalus (Pallas) (Teleostei: Gobiidae: Sicydiinae). Marine and Freshwater Research 59:876-889.

King AJ, Crook DA. 2002. Evaluation of a sweep net electrofishing method for the collection of small fish and shrimp in lotic freshwater environments. Hydrobiologia 472:223-233.

Lamouroux N, Capra H, Pouilly M, Souchon Y. 1999a. Fish habitat preferences in large streams of southern France. Freshwater Biology 42:673-687.

Lamouroux N, Olivier JM, Persat H, Pouilly M, Souchon Y, Statzner B. 1999b. Predicting community characteristics from habitat conditions: fluvial fish and hydraulics. Freshwater Biology 42:275-299.

Lamouroux N, Mérigoux S, Capra H, Dolédec S, Jowett IG, Statzner B. 2010. The generality of abundance-environment relationships in microhabitats: A comment on Lancaster and Downes (2009). River Research and Applications 26:915-920.

Lamouroux N, Mérigoux S, Dolédec S, Snelder TH. 2012. Transferability of hydraulic preference models for aquatic macroinvertebrates. River Research and Applications DOI: $10.1002 / \mathrm{rra}$.

Lancaster J, Downes BJ. 2010. Linking the hydraulic world of individual organisms to 
ecological processes: putting ecology into ecohydraulics. River Research and Applications 26:385-403.

Lefrancois E, Coat S, Lepoint G, Vachiery N, Gros O, Monti D. 2011. Epilithic biofilm as a key factor for small-scale river fisheries on Caribbean islands. Fisheries Management and Ecology 18:211-220.

Leftwich KN, Angermeier PL, Dolloff CA. 1997. Factors influencing behavior and transferability of habitat models for a benthic stream fish. Transactions of the American Fisheries Society 126:725-734.

Lim P, Meunier FJ, Keith P, Noël PY. 2002. Atlas des poissons et crustacés d'eau douce de la Martinique. Muséum national d'Histoire naturelle 51: Paris.

Lord C, Tabouret H, Claverie F, Pecheyran C, Keith P. 2011. Femtosecond laser ablation ICP-MS measurement of otolith Sr:Ca and Ba:Ca composition reveal differential use of freshwater habitats for three amphidromous Sicyopterus (Teleostei: Gobioidei: Sicydiinae) species. Journal of Fish Biology 79:1304-1321.

Malavoi JR, Souchon Y. 1989. Méthodologie de description et quantification des variables morphodynamiques d'un cours d'eau à fond caillouteux. Exemple d'une station sur la

118 March JG, Benstead JP, Pringle CM, Scatena FN. 2003. Damming tropical island streams:

119 Problems, solutions, and alternatives. Bioscience 53:1069-1078.

Mcdowall RM. 2004. Ancestry and amphidromy in island freshwater fish faunas. Fish and Fisheries 5:75-85.

122 Mérigoux S, Lamouroux N, Olivier JM, Dolédec S. 2009. Invertebrate hydraulic preferences and predicted impacts of changes in discharge in a large river. Freshwater Biology 54:1343-1356. 
125 Milton DA. 2009. Living in Two Worlds: Diadromous Fishes, and Factors Affecting

126 Population Connectivity Between Tropical Rivers and Coasts. In Ecological Connectivity among Tropical Coastal Ecosystems, Nagelkerken I (ed.). Springer: Netherlands; 325355.

Mittermeier RA, Gil PR, Hoffman M, Pilgrim J, Brooks T, Mittermeier CG, Lamoreux J, Da Fonseca GAB. 2005. Hotspots revisited: Earth's biologically richest and most endangered terrestrial ecoregions. Conservation International: Washington, DC.

Monti D, Keith P, Vigneux E. 2010. Atlas des poissons et des crustacés d'eau douce de la Guadeloupe. Muséum national d'Histoire naturelle 69: Paris.

Monti D, Legendre P. 2009. Shifts between biotic and physical driving forces of species organization under natural disturbance regimes. Canadian Journal of Fisheries and Aquatic Sciences 66:1282-1293.

Orth DJ, Maughan OE. 1983. Microhabitat Preferences Of Benthic Fauna In A Woodland Stream. Hydrobiologia 106:157-168.

Poff NL, Ward JV. 1989. Implications of streamflow variability and predictability for lotic community structure - a regional-analysis of streamflow patterns. Canadian Journal of

142 Pringle CM, Freeman MC, Freeman BJ. 2000. Regional effects of hydrologic alterations on riverine macrobiota in the New World: tropical-temperate comparisons. BioScience 50:807-823.

R Development Core Team. 2010. R: A language and environment for statistical computing.

148 Robert R. 1988. Géographie de l'eau à l'île de La Réunion: Essai de distribution régionale de 149 l'alimentation et de l'écoulement. Annales de Géographie 539:112-116. 
150 Scatena FN. 2004. A survey of methods for setting minimum instream flow standards in the

151 Caribbean Basin. River Research and Applications 20:127-135.

152 Smith KL, Flores IC, Pringle CM. 2008. A comparison of current and historical fish

153 assemblages in a Caribbean island estuary: conservation value of historical data. Aquatic

$154 \quad$ Conservation-Marine and Freshwater Ecosystems 18:993-1004.

155 Strakosh TR, Neumann RM, Jacobson RA. 2003. Development and assessment of habitat

156 suitability criteria for adult brown trout in southern New England rivers. Ecology of

$157 \quad$ Freshwater Fish 12:265-274.

158 Tabouret H, Lord C, Bareille G, Pecheyran C, Monti D, Keith P. 2011. Otolith

159 microchemistry in Sicydium punctatum: indices of environmental condition changes after

160 recruitment. Aquatic Living Resources 24:369-378.

161 Tew KS, Han CC, Chou WR, Fang LS. 2002. Habitat and fish fauna structure in a subtropical

162 mountain stream in Taiwan before and after a catastrophic typhoon. Environmental

163 Biology of Fishes 65:457-462.

164 Tharme RE. 2003. A global perspective on environmental flow assessment: emerging trends

165 in the development and application of environmental flow methodologies for rivers. River

$166 \quad$ Research and Applications 19:397-441.

167 Vaudor L, Lamouroux N, Olivier JM. 2011. Comparing distribution models for small samples

168 of overdispersed counts of freshwater fish. Acta Oecologica-International Journal of

169 Ecology 37:170-178.

170 Vilizzi L, Copp GH, Roussel JM. 2004. Assessing variation in suitability curves and electivity 171 profiles in temporal studies of fish habitat use. River Research and Applications 20:605172618.

173 Wood SN. 2006. Generalized Additive Models: An Introduction with R. Chapman and

174 Hall/CRC: Boca Raton, FL. 
Author-produced version of the article published in River Research and Applications (2014), vol. 30, Issue 6, pages 766-779

The original publication is available at http://onlinelibrary.wiley.com, doi : 10.1002/rra.2675

176 Table 1: Datasets characteristics

\begin{tabular}{|c|c|c|c|c|c|c|c|}
\hline \multirow{2}{*}{$\begin{array}{l}\begin{array}{l}\text { Dataset } \\
\text { code }\end{array} \\
\text { Caribbea }\end{array}$} & \multirow[t]{2}{*}{ Island } & \multirow[t]{2}{*}{$\begin{array}{l}\text { Sampling } \\
\text { method }\end{array}$} & \multirow[t]{2}{*}{$\begin{array}{l}\text { Number of } \\
\text { surveys }\end{array}$} & \multicolumn{2}{|c|}{$\begin{array}{l}\text { Number of samples } \\
\text { (min-max per station) }\end{array}$} & \multirow[t]{2}{*}{$\begin{array}{l}\text { Sampling } \\
\text { Years }\end{array}$} & \multirow[t]{2}{*}{$\begin{array}{l}\text { Number of } \\
\text { taxa sampled }\end{array}$} \\
\hline & & & & & & & \\
\hline $\mathrm{Gp}$ & Guadeloupe & Points & 32 & 1455 & $(10-52)$ & $2005,2008,2009$ & 23 \\
\hline $\mathrm{Gq}$ & Guadeloupe & Quadrats & 27 & 1811 & $(79-99)$ & 2005 & 22 \\
\hline $\mathrm{Mp}$ & Martinique & Points & 21 & 946 & $(31-50)$ & 2008,2010 & 21 \\
\hline \multicolumn{8}{|c|}{ Indian Ocean } \\
\hline $\mathrm{Rp}$ & Réunion & Points & 17 & 1359 & $(13-85)$ & 1999,2001 & 25 \\
\hline $\mathrm{Rh}$ & Réunion & Habitat units & 196 & 3284 & $(3-21)$ & $2000-2011$ & 28 \\
\hline
\end{tabular}

177 
lected taxa and their main ecological characteristics. Habitat use and feeding groups are summarized from information detailed in Coat $e t$ al. (2009, 2011), Keith $e$ al. (1999), Lim et al. (2002) and Monti et al. (2010). Abbreviations for feeding guilds are: $\mathrm{F}$ for filter feeding, $\mathrm{H}$ for Herbivore, $\mathrm{D}$ for Detritivore, $\mathrm{O}$ for Omnivore. $\theta\left(\sigma_{\theta}\right)$ is the dispersion coefficient (and its standard error) fitted for the taxa.

\begin{tabular}{|c|c|c|c|c|c|c|c|c|c|}
\hline $\begin{array}{l}\text { Taxa } \\
\text { Code }\end{array}$ & Taxa & Family & Habitat use & $\begin{array}{l}\text { Feeding } \\
\text { group }\end{array}$ & $\begin{array}{c}\text { Number of } \\
\text { occurrence } \\
\text { in sample }\end{array}$ & $\begin{array}{l}\text { Number of } \\
\text { individuals }\end{array}$ & $\theta$ & $\sigma_{\theta}$ & $\begin{array}{l}\text { Mean size } \\
\quad(\mathrm{mm})\end{array}$ \\
\hline \multicolumn{10}{|c|}{ Caribbean } \\
\hline AIN & Atya innocous (Herbst, 1972) & Atyidae & Rapid & $\mathrm{F}, \mathrm{D} / \mathrm{H}$ & 1139 & 8873 & 0.22 & 0.01 & 47 \\
\hline ASC & Atya scabra (Leach, 1815) & Atyidae & Rapid & $\mathrm{F}, \mathrm{D} / \mathrm{H}$ & 391 & 1556 & 0.06 & 0.00 & 51 \\
\hline ASP & Atya sp. (juvenile) & Atyidae & & & 560 & 2135 & 0.09 & 0.00 & \\
\hline MPO & Micratya poeyi (Guérin-Méneville, 1885) & Atyidae & Vegetation & $\mathrm{F}, \mathrm{D} / \mathrm{H}$ & 2407 & 25759 & 0.46 & 0.01 & 18 \\
\hline XEL & Xiphocaris elongata (Guérin-Méneville, 1855) & Xiphocariidae & Pool, river banks & $\mathrm{D} / \mathrm{H}$ & 956 & 5513 & 0.11 & 0.00 & 44 \\
\hline MCR & Macrobrachium crenulatum (Holthuis, 1950) & Palaemonidae & Rapid, deep run & $\mathrm{O}$ & 345 & 565 & 0.06 & 0.00 & 57 \\
\hline MFA & Macrobrachium faustinum (de Saussure, 1857) & Palaemonidae & Pool, shelter & $\mathrm{O}$ & 1814 & 5657 & 0.34 & 0.01 & 42 \\
\hline MHE & Macrobrachium heterochirus (Wiegmann, 1836) & Palaemonidae & Rapid & $\mathrm{O}$ & 1010 & 1793 & 0.14 & 0.01 & 48 \\
\hline MSP & Macrobrachium sp. (juvenile) & Palaemonidae & & & 1147 & 2984 & 0.17 & 0.01 & \\
\hline AMO & Agonostomus monticola (Bancroft, 1834) & Mugilidae & Rapid & $\mathrm{D} / \mathrm{H}$ & 307 & 617 & 0.06 & 0.00 & 124 \\
\hline SIC & Sicydium sp. (Perugia, 1986; Bloch, 1786) & Gobiidae & Rapid & $\mathrm{H}$ & 2208 & 11658 & 0.32 & 0.01 & 50 \\
\hline \multicolumn{10}{|c|}{ Indian Ocean } \\
\hline ATY & Atyoida serrata (Bate, 1888) & Atyidae & Rapid, vegetation & $\mathrm{F}, \mathrm{D} / \mathrm{H}$ & 532 & 2974 & 0.32 & 0.01 & 18 \\
\hline MAA & Macrobrachium australe (Guérin-Méneville, 1838) & Palaemonidae & Pool & $\mathrm{O}$ & 476 & 1444 & 0.51 & 0.02 & 42 \\
\hline $\mathrm{COA}$ & Cotylopus acutipinnis (Guichenot, 1863) & Gobiidae & Rapid & $\mathrm{H}$ & 1033 & 2719 & 0.92 & 0.03 & 44 \\
\hline SLA & Sicyopterus lagocephalus (Pallas, 1770) & Gobiidae & Rapid & $\mathrm{H}$ & 2423 & 11512 & 1.10 & 0.03 & 60 \\
\hline
\end{tabular}


Table 3: Explained deviance for M1 (\% of the initial deviance) and supplementary deviance $\mathrm{M}_{\mathrm{i}} / \mathrm{M}_{\mathrm{i}-1}(\%$ of the residual deviance of $\mathrm{M}_{\mathrm{i}-1}$ explained by $\mathrm{M}_{\mathrm{i}}$ ). Additional deviance is shown for significant cases only ( $\mathrm{P}$-value $<0.05)$.

\begin{tabular}{|c|c|c|c|c|c|c|c|c|c|c|}
\hline & \multirow[b]{2}{*}{ Taxon } & \multirow[b]{2}{*}{ M1 } & \multirow[b]{2}{*}{$\begin{array}{l}\text { Hydraulic } \\
\text { parameter }\end{array}$} & \multirow[b]{2}{*}{$\mathrm{M} 2 / \mathrm{M} 1$} & \multirow[b]{2}{*}{ M3/M2 } & \multicolumn{5}{|c|}{ M4/M3 } \\
\hline & & & & & & Altitude & $\begin{array}{l}\text { With- } \\
\text { drawals }\end{array}$ & $\begin{array}{c}\text { Coast } \\
\text { exposure }\end{array}$ & $\begin{array}{c}\text { Basin } \\
\text { surface } \\
\text { area }\end{array}$ & years \\
\hline \multirow{33}{*}{ Caribbean } & AIN & 52.4 & $\mathrm{v}$ & 2.8 & - & - & - & - & - & - \\
\hline & & & $\mathrm{h}$ & 1.2 & 0.5 & 0.4 & - & - & - & - \\
\hline & & & $d$ & 0.4 & 0.6 & - & - & - & - & 0.4 \\
\hline & AMO & 20.3 & $\mathrm{v}$ & - & - & - & - & - & - & - \\
\hline & & & $\mathrm{h}$ & 4.0 & 2.2 & 0.6 & - & - & - & - \\
\hline & & & $d$ & - & - & - & - & - & - & - \\
\hline & ASC & 30.7 & $\mathrm{v}$ & 18.1 & 1.5 & - & - & 0.8 & - & - \\
\hline & & & $\mathrm{h}$ & 5.4 & 0.9 & 2.2 & 1.1 & 2.0 & 1.2 & 1.2 \\
\hline & & & $d$ & 3.9 & - & - & - & - & - & - \\
\hline & ASP & 20.9 & $\mathrm{v}$ & 1.9 & - & - & - & - & 0.5 & - \\
\hline & & & $\mathrm{h}$ & 2.6 & 0.9 & 0.7 & 1.0 & - & 0.4 & - \\
\hline & & & $d$ & - & 1.2 & - & - & - & 0.5 & - \\
\hline & MCR & 32.3 & $\mathrm{v}$ & 3.1 & - & - & - & 0.7 & - & - \\
\hline & & & $\mathrm{h}$ & 0.5 & - & - & - & - & - & - \\
\hline & & & d & - & 0.8 & - & - & - & - & - \\
\hline & MFA & 30.9 & $\mathrm{v}$ & 1.6 & 0.3 & - & 0.6 & 0.1 & 0.5 & - \\
\hline & & & $\mathrm{h}$ & 0.9 & - & 0.4 & 0.2 & - & 0.4 & - \\
\hline & & & $d$ & 0.5 & - & - & - & - & 0.2 & - \\
\hline & MHE & 24.3 & $\mathrm{v}$ & 7.1 & 0.7 & - & - & - & - & - \\
\hline & & & $\mathrm{h}$ & 1.5 & 0.8 & - & - & 0.4 & 0.6 & 0.3 \\
\hline & & & $d$ & 1.0 & 0.4 & - & 0.2 & 0.3 & - & 0.3 \\
\hline & MPO & 45.0 & $\mathrm{v}$ & 3.3 & 0.3 & 0.2 & - & - & 0.2 & - \\
\hline & & & $\mathrm{h}$ & 2.9 & 1.1 & - & - & - & - & 0.2 \\
\hline & & & d & 0.9 & 0.4 & 0.6 & - & - & - & - \\
\hline & MSP & 28.1 & $\mathrm{v}$ & 1.1 & 0.9 & - & 0.5 & - & - & - \\
\hline & & & $\mathrm{h}$ & 1.7 & 0.5 & - & 0.2 & 0.3 & 0.3 & 0.5 \\
\hline & & & $d$ & 0.5 & - & - & - & - & - & 0.3 \\
\hline & SIC & 33.2 & $\mathrm{v}$ & 3.8 & 0.5 & 0.1 & - & 0.2 & 0.3 & 0.1 \\
\hline & & & $\mathrm{h}$ & 2.8 & 0.8 & 0.2 & 0.3 & - & 0.3 & - \\
\hline & & & $d$ & 0.3 & - & - & - & - & 0.1 & - \\
\hline & XEL & 29.7 & $\mathrm{v}$ & 8.1 & - & 1.0 & 0.4 & - & 0.8 & - \\
\hline & & & $\mathrm{h}$ & 2.4 & 0.7 & 0.4 & - & 0.4 & - & - \\
\hline & & & $\mathrm{d}$ & - & 0.7 & - & - & - & - & - \\
\hline \multirow{12}{*}{$\begin{array}{l}\text { Indian } \\
\text { Ocean }\end{array}$} & ATY & 48.7 & $\mathrm{v}$ & 3.0 & - & 2.4 & & 0.5 & - & - \\
\hline & & & $\mathrm{h}$ & 5.6 & - & 0.4 & & - & 0.8 & 0.6 \\
\hline & & & $d$ & 1.6 & 1.0 & 0.5 & & - & 0.9 & - \\
\hline & $\mathrm{COA}$ & 56.0 & $\mathrm{v}$ & 9.3 & 1.5 & 1.4 & & - & 2.1 & 0.2 \\
\hline & & & $\mathrm{h}$ & 5.3 & 1.5 & 1.3 & & - & - & - \\
\hline & & & $d$ & 1.1 & - & - & & 0.5 & - & 0.0 \\
\hline & MAA & 44.4 & $\mathrm{v}$ & 5.4 & - & - & & 0.3 & 1.9 & 2.4 \\
\hline & & & $\mathrm{h}$ & 1.4 & 1.5 & - & & 0.4 & - & 1.7 \\
\hline & & & $d$ & 3.0 & 0.9 & - & & 1.3 & - & 0.0 \\
\hline & SLA & 39.7 & $\mathrm{v}$ & 16.9 & 0.3 & 1.3 & & 0.3 & 0.8 & - \\
\hline & & & $\mathrm{h}$ & 13.5 & 0.9 & 1.6 & & 0.5 & 1.1 & - \\
\hline & & & $\mathrm{d}$ & 2.7 & - & 0.3 & & - & 0.6 & - \\
\hline
\end{tabular}


186 Table 4: Supplementary deviance M2/M1 (\% of the residual deviance of M1 explained by M2) for size classes.

187 Additional deviance is shown for significant cases only ( $\mathrm{P}$-value $<0.05)$.

\begin{tabular}{|c|c|c|c|c|c|c|}
\hline \multirow{2}{*}{ Region } & \multirow{2}{*}{ Taxon } & \multirow{2}{*}{\multicolumn{2}{|c|}{$\begin{array}{c}\text { Size } \\
\text { class }(\mathrm{mm})\end{array}$}} & \multicolumn{3}{|c|}{$\mathrm{M} 2 / \mathrm{M} 1$} \\
\hline & & & & $\mathrm{V}$ & $\mathrm{h}$ & $\mathrm{d}$ \\
\hline \multirow{18}{*}{ Caribbean } & AIN & $\leq$ & 45 & 2.7 & 2.5 & - \\
\hline & & $>$ & 45 & 2.4 & 1.2 & - \\
\hline & AMO & $\leq$ & 115 & 1.8 & - & 1.1 \\
\hline & & $>$ & 115 & - & 7.7 & 1.3 \\
\hline & ASC & $\leq$ & 50 & 20.9 & 10.1 & 3.1 \\
\hline & & $>$ & 50 & 16.9 & 3.2 & 5.2 \\
\hline & MCR & $\leq$ & 55 & 1.3 & 2.5 & - \\
\hline & & $>$ & 55 & 2.8 & 1.7 & - \\
\hline & MFA & $\leq$ & 40 & 2.1 & 0.5 & 0.5 \\
\hline & & $>$ & 40 & 3.0 & 1.6 & 0.6 \\
\hline & MHE & $\leq$ & 45 & 7.4 & 3.3 & 2.0 \\
\hline & & $>$ & 45 & 6.0 & 1.4 & 0.9 \\
\hline & MPO & $\leq$ & 15 & 2.1 & 4.3 & 0.5 \\
\hline & & $>$ & 15 & 3.2 & 4.5 & 0.8 \\
\hline & SIC & $\leq$ & 45 & 2.6 & 5.4 & - \\
\hline & & $>$ & 45 & 5.5 & 2.5 & 0.5 \\
\hline & XEL & $\leq$ & 40 & 11.0 & - & - \\
\hline & & $>$ & 40 & 8.8 & 2.5 & - \\
\hline \multirow{8}{*}{$\begin{array}{l}\text { Indian } \\
\text { Ocean }\end{array}$} & ATY & $\leq$ & 20 & 3.1 & 6.0 & - \\
\hline & & $>$ & 20 & 3.7 & 5.2 & 4.3 \\
\hline & $\mathrm{COA}$ & $\leq$ & 35 & 8.2 & 9.4 & 0.5 \\
\hline & & $>$ & 35 & 8.5 & 4.1 & 1.3 \\
\hline & MAA & $\leq$ & 40 & 7.4 & 2.1 & 3.6 \\
\hline & & $>$ & 40 & 3.8 & 1.4 & 1.2 \\
\hline & SLA & $\leq$ & 55 & 11.6 & 13.6 & 1.0 \\
\hline & & $>$ & 55 & 16.2 & 9.7 & 3.7 \\
\hline
\end{tabular}

188 
190 Table 5: Explained deviance for M1 (\% of the initial deviance) and supplementary deviance $\mathrm{M}_{\mathrm{i}} / \mathrm{M}_{\mathrm{i}-1}(\%$ of the

191 residual deviance of $\mathrm{M}_{\mathrm{i}-1}$ explained by $\mathrm{M}_{\mathrm{i}}$ ). Additional deviance is shown for significant cases only ( $\mathrm{P}$-value

$192<0.05$ ).

\begin{tabular}{llccc}
\hline Region & Taxon & M1 & M5/M1 & M6/M5 \\
\hline \multirow{4}{*}{ Caribbean } & AIN & 52.4 & 3.8 & 1.4 \\
& AMO & 20.3 & 4.6 & 2.8 \\
& ASC & 30.7 & 23.7 & 0.9 \\
& ASP & 20.9 & 4.1 & 2.8 \\
& MCR & 32.3 & 3.3 & 1.5 \\
& MFA & 30.9 & 2.8 & 1.3 \\
& MHE & 24.3 & 8.3 & 1.0 \\
& MPO & 45.0 & 6.5 & 1.2 \\
& MSP & 28.1 & 3.3 & 2.7 \\
Indian & SIC & 33.2 & 6.4 & 3.7 \\
& XEL & 29.7 & 10.1 & 5.3 \\
\hline & ATY & 48.7 & 9.2 & 1.7 \\
& MAA & 56.0 & 11.0 & 9.4 \\
& SLA & 44.4 & 3.6 & 2.5 \\
\hline
\end{tabular}

193

194

195

196 


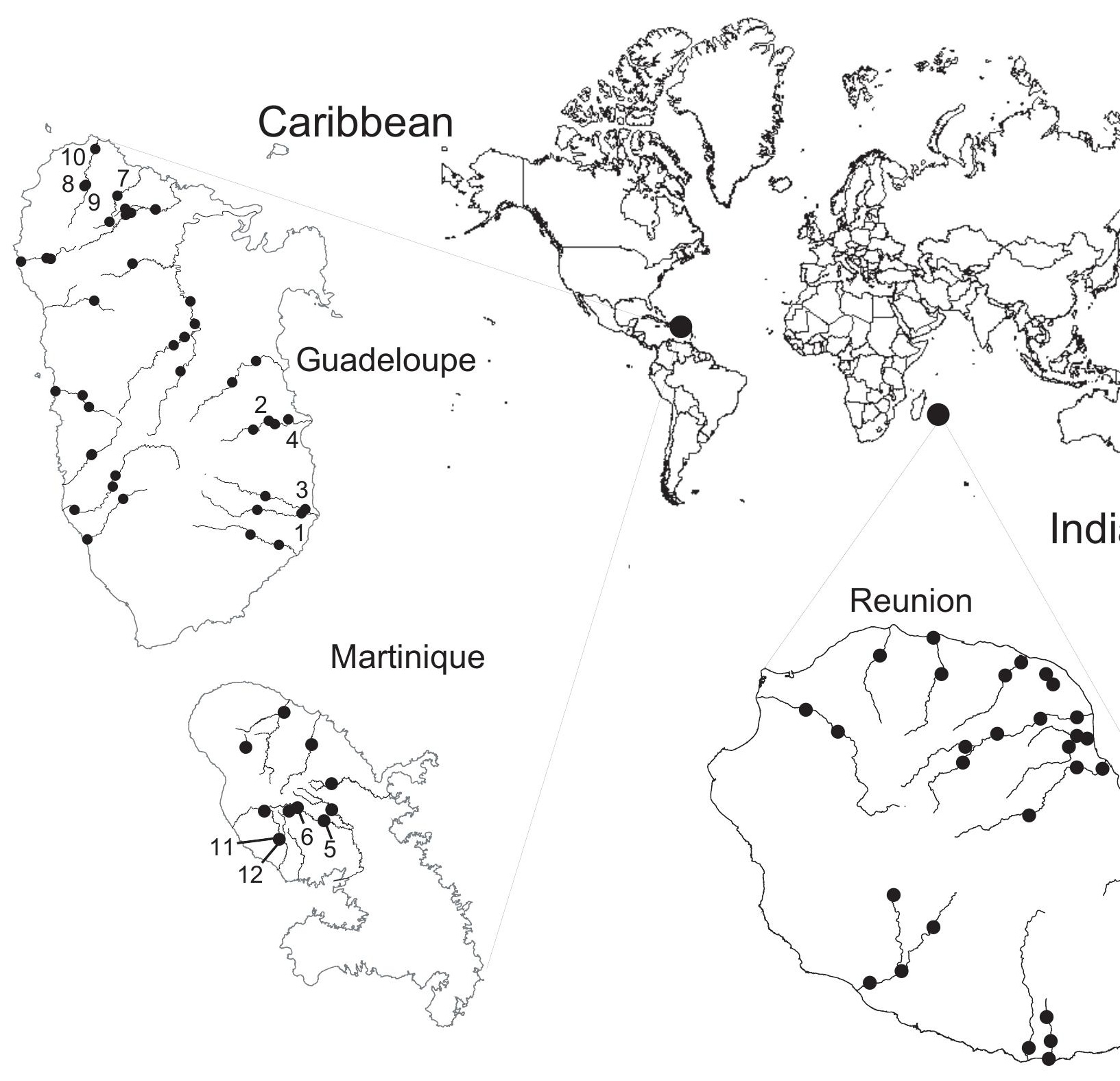


(a) Gp, station 1

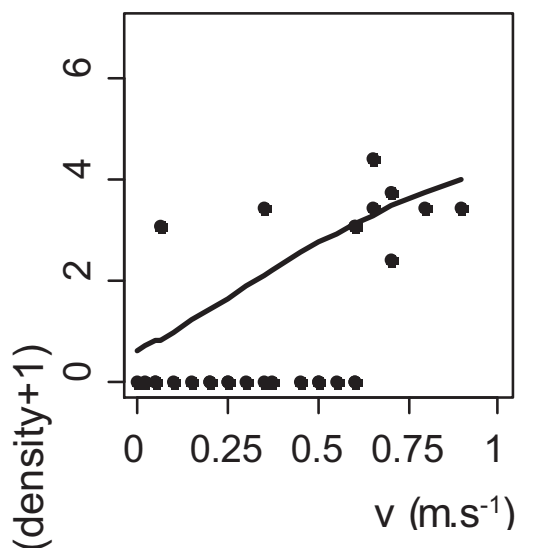

Gq, station 4

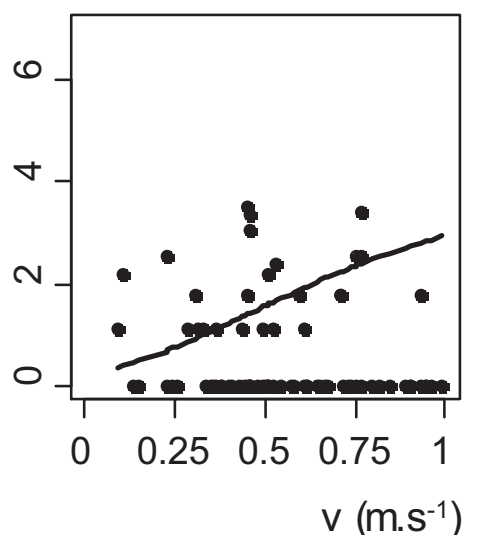

(b) Gp, station 7

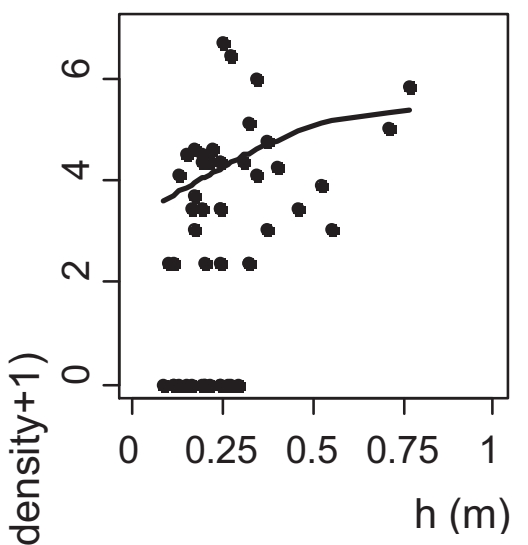

$\mathrm{Gq}$, station 10

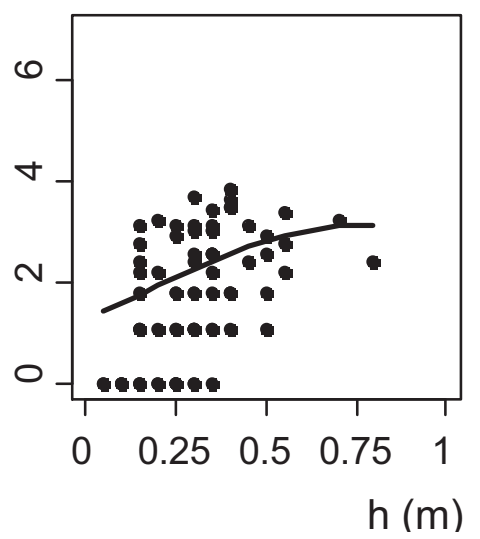

Gp, station 2

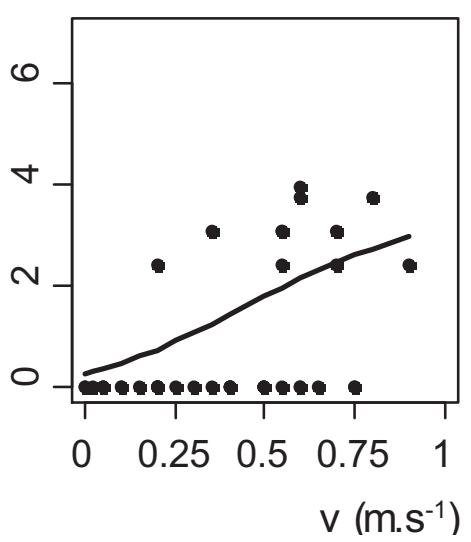

Mp, station 5

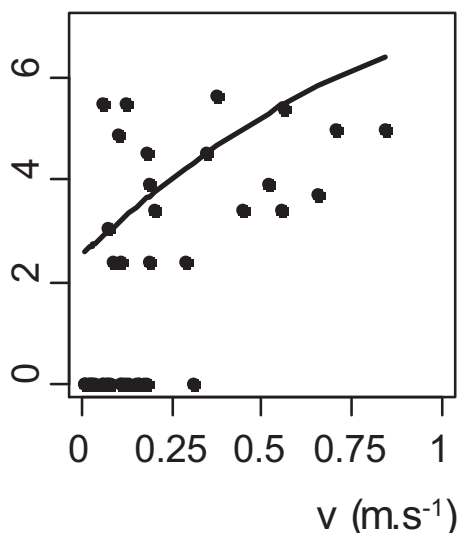

Gp, station 8

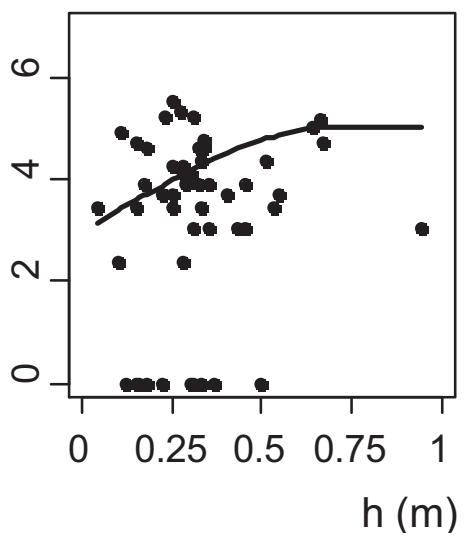

Mp, station 11

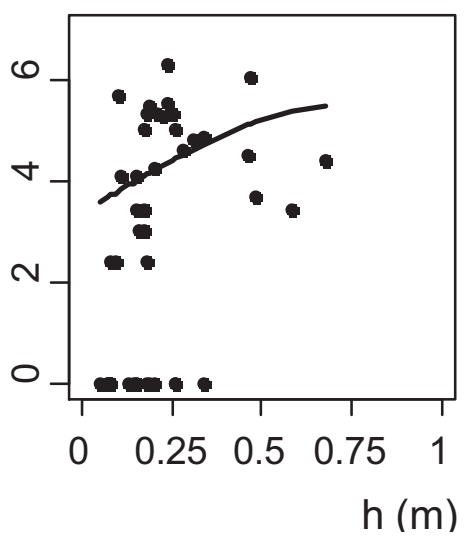

Gq, station 3

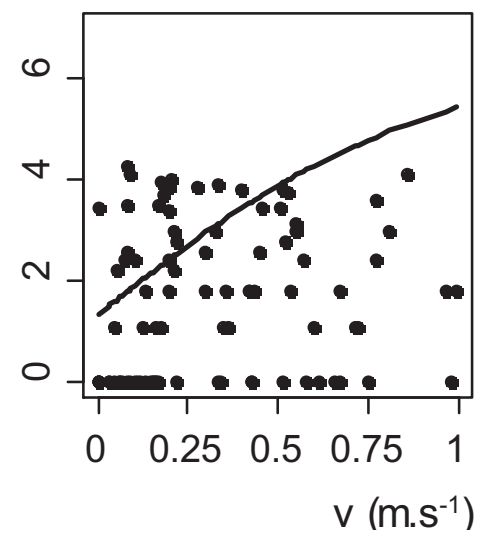

$\mathrm{Mp}$, station 6

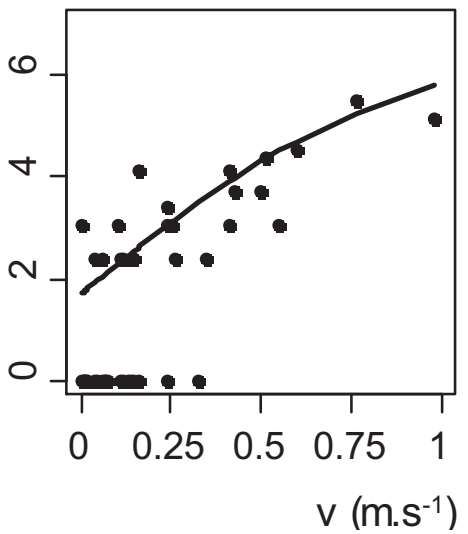

Gq, station 9

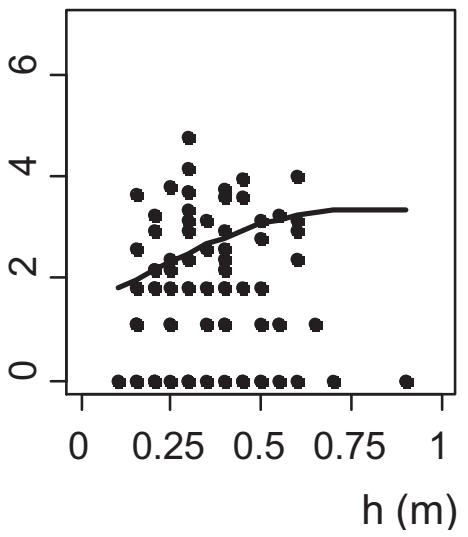

Mp, station 12

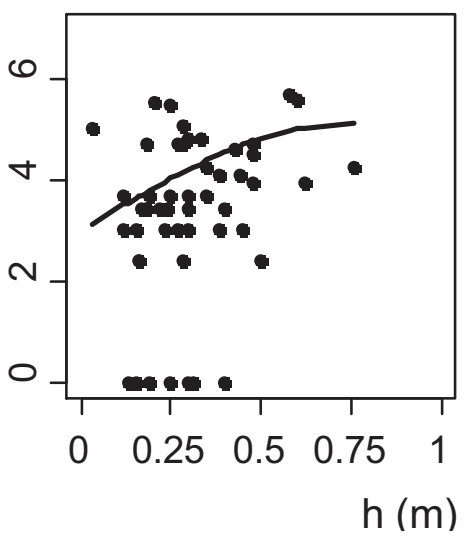


(a) A. scabra
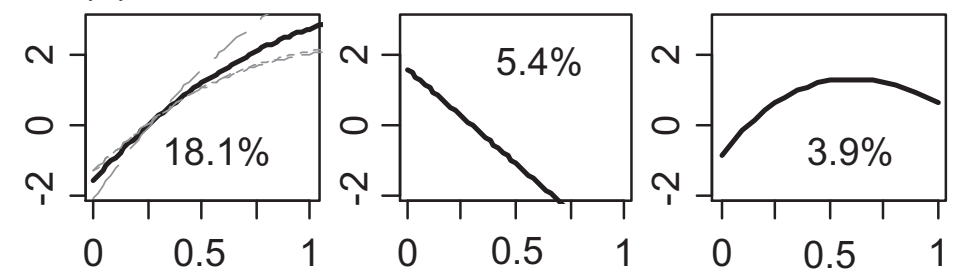

(b) M. heterochirus
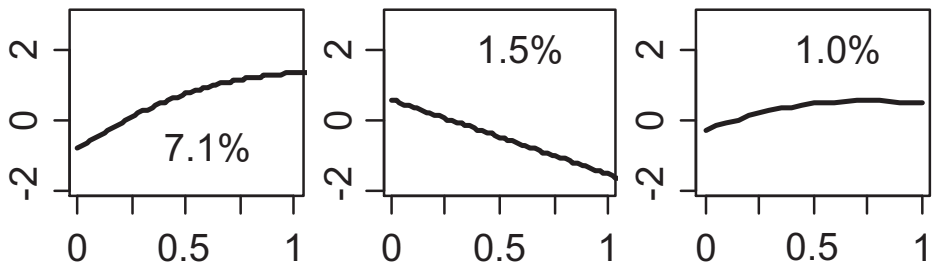

(c) X. elongata

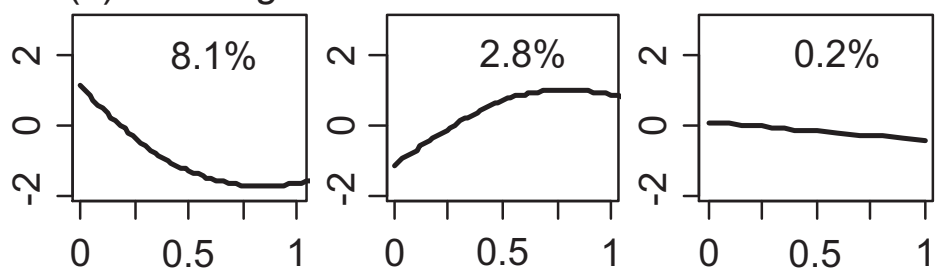

(d) Sicydium sp.
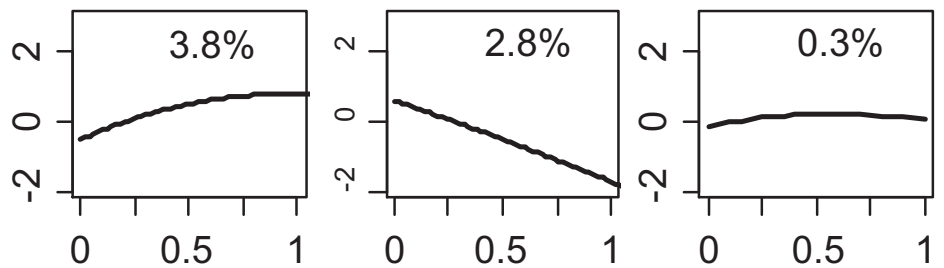

(e) A.monticola

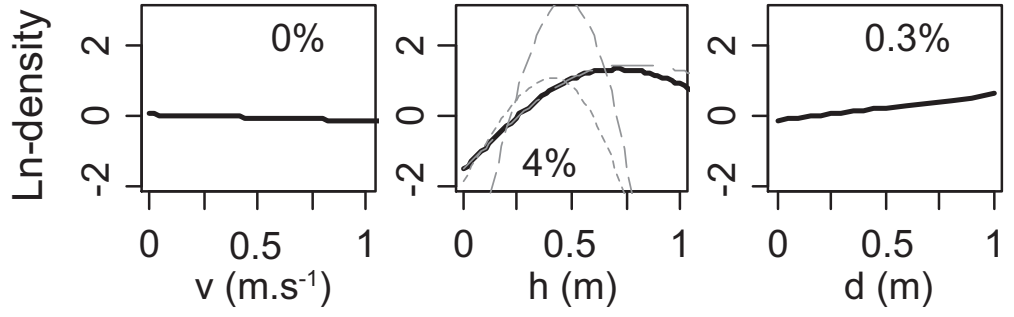


(a) A. serrata

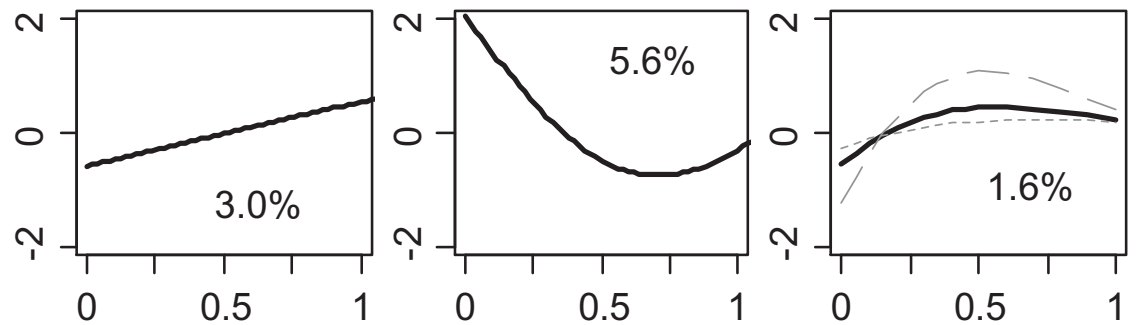

(b) C. acutipinnis
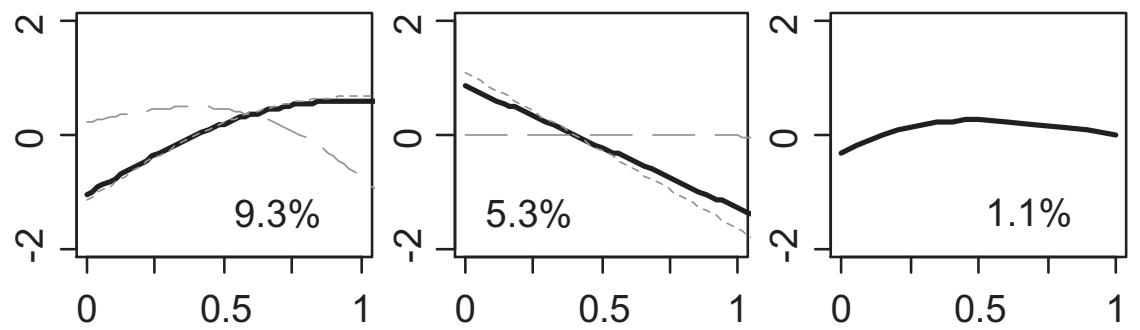

(c) M. australe
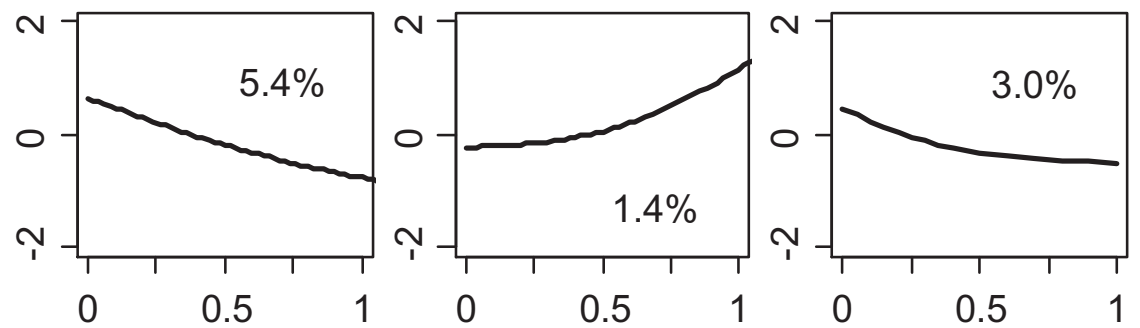

(d) S. lagocephalus
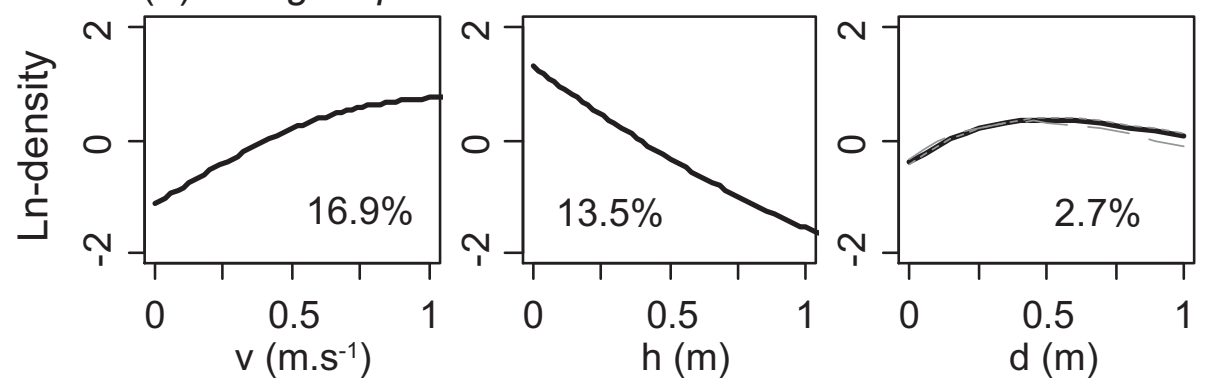
(a) X. elongata

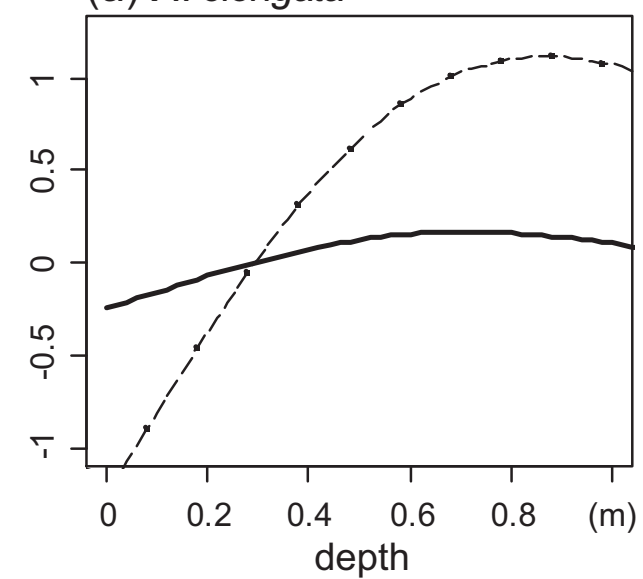

(b) M. heterochirus

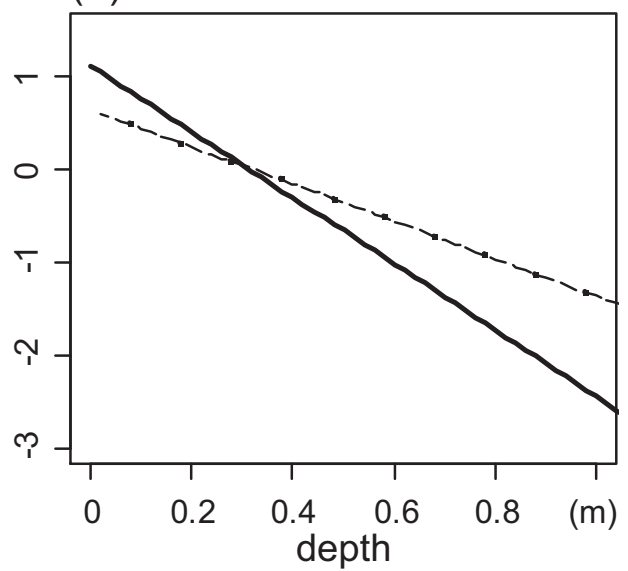

(c) S. lagocephalus

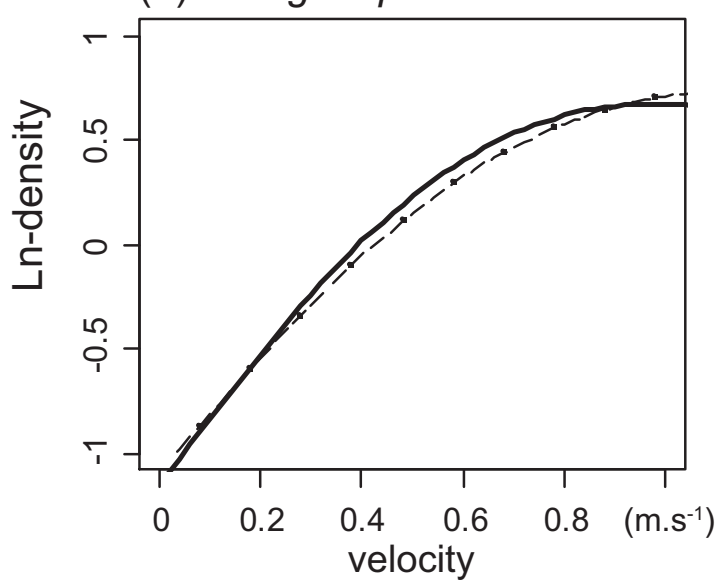

Sicydium sp.

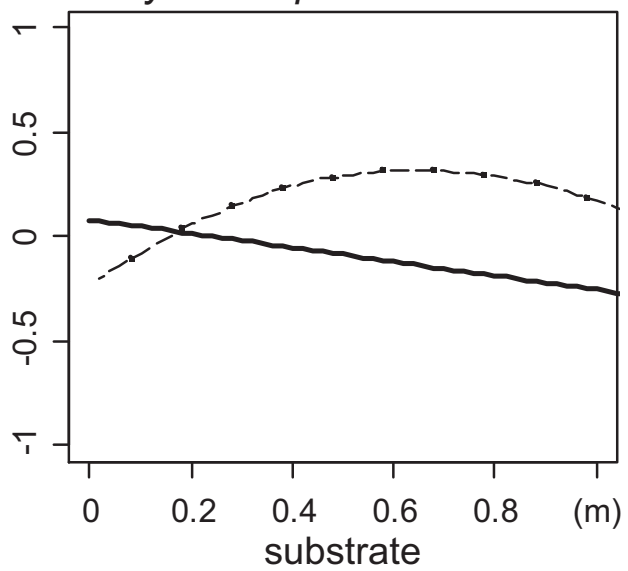

M. faustinum

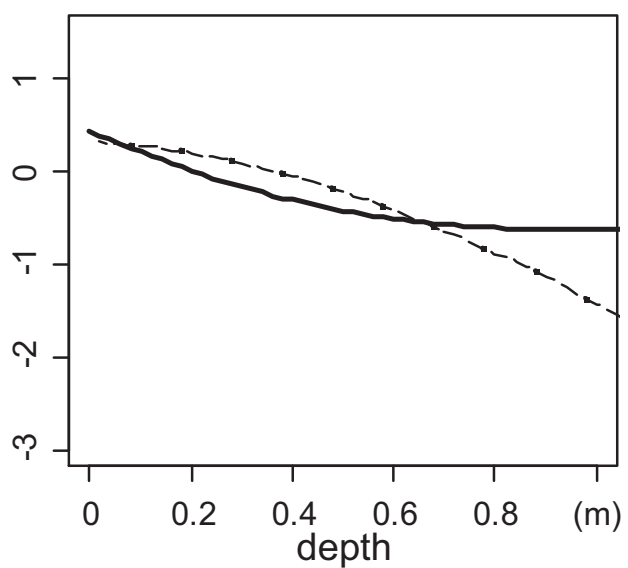

C. acutipinnis

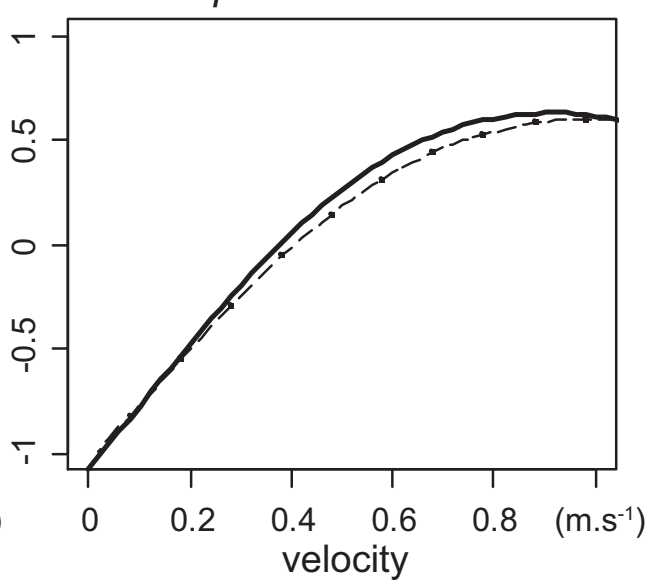

